\title{
Ethyl Carbamate Production Kinetics during Wine Storage
}

\author{
J. Xue ${ }^{1, *}$, F. Fu ${ }^{2}$, M. Liang ${ }^{2}$, C. Zhao ${ }^{1}$, D. Wang, ${ }^{1}{ }^{1}$. Wu ${ }^{2 *}$ \\ (1) China National Research Institute for Food and Fermentation Industries, Beijing 10027, China \\ (2) Department of Food Science and Pharmacy, XinJiang Agricultural University, Urumchi 830052, China
}

Submitted for publication: December 2014

Accepted for publication: March 2015

Key words: Wine, ethyl carbamate, production kinetics, urea, temperature, citrulline

\begin{abstract}
The kinetics of ethyl carbamate (EC) formation was investigated during wine storage to evaluate the potential risk of EC formation in wine. The study monitored the EC, urea and citrulline concentration at different storage temperatures and wine $\mathrm{pH}$. We found that temperature and initial urea content had significant effects on EC formation. The decay of urea and citrulline fit a first-order reaction approaching equilibrium, but the $\mathrm{pH}$ has little effect on the content of ethyl carbamate. Based on these results, we constructed an equation to forecast the content of ethyl carbamate during wine storage.
\end{abstract}

\section{INTRODUCTION}

Ethyl carbamate, also known as urethane $\left(\mathrm{C}_{2} \mathrm{H}_{5} \mathrm{COONH}_{2}\right)$, has been recognised as "probably carcinogenic to humans" by the IRAC (International Agency for Research on Cancer) since 2007 (Lachenmeier et al., 2009; Larcher et al., 2013). It has been linked to lung cancer, lymph cancer, liver cancer, skin cancer and many others. Ethanol promotes the carcinogenicity of EC (Miller et al., 2003; Beland et al., 2005). The mean intake of EC from fermented foods and drinks can reach several milligrams per litre (Ough, 1976). This excludes the contribution of alcoholic beverages. At the 64th meeting of the JECFA (Joint Expert Committee on Food Additives) it was suggested that reduced consumption of ethyl carbamate would protect human health (Liang et al., 2009).

In recent years, the consumption of wine in China has experienced strong growth, with special attention being given to the amount of ethyl carbamate in these products (Park et al., 2009; Shijia Wu, 2009). Uthurry et al. (2004) found that, in newly produced wines, the concentration of $\mathrm{EC}$ is 1 to $10 \mu \mathrm{g} / \mathrm{L}$, although the storage conditions and time determine the final concentration at the time of consumption (Hasnip et al., 2004). The major precursors of EC are urea and citrulline (Ough et al., 1988; Stevens \& Ough, 1993; Liu et al., 1994). EC is formed from the reaction of urea and ethanol (Eq. 1) or urea and citrulline (Eq. 2) taking place during alcohol production and preservation (Delledonne et al., 2001; Wang et al., 2007; Weber \& Sharypov, 2009). Several studies have shown that the formation of EC is significantly accelerated by high concentrations of ethanol, urea and citrulline. Stevens and Ough (1993) studied the relationship between urea, ethanol and the formation of $\mathrm{EC}$ at different temperatures and showed that the concentration of urea in wine should not exceed $2 \mathrm{mg} / \mathrm{L}$. Higher concentrations risk potential concentrations of EC that exceed the American non-preemptive limit of $15 \mu \mathrm{g} / \mathrm{L}$ (Stevens \& Ough, 1993).

$$
\begin{aligned}
& \mathrm{NH}_{2} \mathrm{CONH}_{2}+\mathrm{C}_{2} \mathrm{H}_{5} \mathrm{OH} \rightarrow \mathrm{NH}_{2} \mathrm{COOC}_{2} \mathrm{H}_{5}+\mathrm{NH}_{3} \\
& \mathrm{H}_{2} \mathrm{NCONH}_{2}\left(\mathrm{CH}_{2}\right)_{3} \mathrm{CH}\left(\mathrm{NH}_{2}\right) \mathrm{COOH}+\mathrm{C}_{2} \mathrm{H}_{5} \mathrm{OH} \rightarrow \\
& \mathrm{NH}_{2} \mathrm{COOC}_{2} \mathrm{H}_{5}+\mathrm{H}_{2} \mathrm{~N}\left(\mathrm{CH}_{2}\right)_{3} \mathrm{CH}\left(\mathrm{NH}_{2}\right) \mathrm{COOH}
\end{aligned}
$$

Here we study changes to ethyl carbamate's concentration in wine during storage, including the influence of storage temperature, $\mathrm{pH}$ and the content of urea and citrulline in wine on the final concentration of EC. We constructed simple methods to predict the concentration of EC during storage and thus hope to reduce the amount of EC in wine. These tools may also form the theoretical basis for future limit standards of EC in Chinese wine.

\section{MATERIALS AND METHODS \\ Materials}

Two red wines and one white wine were produced on a laboratory scale (20 L) from Cabernet Sauvignon, Merlot and Chardonnay in 2011. Red wines were fermented at 25 $\pm 1^{\circ} \mathrm{C}$ using Lallemand D254 yeast strain and Lallemand VP41 lactobacillus. The white wine was fermented at $20 \pm$ $1{ }^{\circ} \mathrm{C}$ using Lallemand DV10 yeast strain. After fermentation the wines were sulphited $(60 \mathrm{mg} / \mathrm{L})$, and they there were subjected to batonnage at 12 to $15^{\circ} \mathrm{C}$ three times a week for 1.5 months, sterile filtered $(0.45 \mu \mathrm{m})$, and the red wine from Cabernet Sauvignon was stored in a gallon carboy during storage to remove the sample from the bottom. The bottle headspace was limited to minimise ethanol evaporation. The other wines were bottled $(250 \mathrm{~mL})$.

At the time of storage or bottling, the wines had the following composition (Cabernet Sauvignon, Merlot and Chardonnay respectively): alcohol content $11.9,13.6$ and $10.8 \%(\mathrm{v} / \mathrm{v}) ; \mathrm{pH} 3.32,3.67$ and 3.23 ; residual sugars 0.82 , 1.24 and $4.06 \mathrm{~g} / \mathrm{L}$; total $\mathrm{SO}_{2} 75,94$ and $186 \mathrm{mg} / \mathrm{L}$; urea

*Corresponding author: Jie Xue, e-mail address: lxxuejie@126.com; YunWu,e-mail address: 764630324@qq.com

Acknowledgements: This work was supported by the National Natural Science Foundation (31360406) project of the Xin Jiang Autonomous Region Science and Technology Plans (201431113), and by the Ministry of Science and Technology, People's Republic of China under grant no. 2013AA102108 
content $0.83,2.26$ and $6.82 \mathrm{mg} / \mathrm{L}$; and citrulline content $0.56,6.72$ and $1.34 \mathrm{mg} / \mathrm{L}$.

\section{Experimental treatment}

First, $8 \mathrm{~L}$ of Cabernet Sauvignon red wine were mixed in a gallon carboy and then split into two volumetric flasks. One was spiked with urea and the other was spiked with citrulline to bring the concentrations of urea and citrulline to $5.1 \mathrm{mg} / \mathrm{L}$ and $5.73 \mathrm{mg} / \mathrm{L}$, respectively. These were then split into four $1 \mathrm{~L}$ gallon carboys and stored at $15^{\circ} \mathrm{C}, 20^{\circ} \mathrm{C}, 25^{\circ} \mathrm{C}$ and $30^{\circ} \mathrm{C}$, respectively.

Urea was added to confirm that the initial concentration of urea in the Cabernet Sauvignon red wine was $10.1 \mathrm{mg} / \mathrm{L}$, $15.1 \mathrm{mg} / \mathrm{L}$ and $20.1 \mathrm{mg} / \mathrm{L}$, respectively. These samples were stored at $20^{\circ} \mathrm{C}$. The test studied how the initial concentration of urea effects the formation of EC. The experiment used buffer solution to adjust the sample wine $\mathrm{pH}$ to $3.0,3.25$, and 3.5 , with the initial concentrations of urea being $5.1 \mathrm{mg} / \mathrm{L}$. The samples were stored at $25^{\circ} \mathrm{C}$.

The other bottled wines (white and red) were placed in temperature-controlled storage at 18 and $23^{\circ} \mathrm{C}$, respectively. To help validate the model in this research, the levels of EC, urea and citrulline were measured at intervals for up to one year in the course of storage.

\section{Major chemical reagents}

We purchased ethyl carbamate (EC) (purity $>99 \%$ ) and the internal standard propyl carbamate (nPC) (purity $>99 \%$ ) from Sigma. Acetone (chromatographically pure), methylene dichloride (analytically pure), urea (analytically pure) and citrulline (chromatographically pure) were purchased from $\mathrm{J} \& \mathrm{~K}$.

\section{Analysis of EC, urea and citrulline}

The content of EC was determined according to the method of De Melo Abre et al. (2005) using a GC-MS (Perkin-Elmer, USA) equipped with a capillary WAX ETR column (30 m, $0.25 \mathrm{~mm}, 0.25 \mathrm{um}$; Perkin-Elmer, USA). Wine samples of $2.0 \mathrm{~mL}$, with the addition of $1 \mathrm{~mL}$ of propyl carbamate (400 $\mathrm{ng} / \mathrm{mL}$ in water) as an internal standard, were extracted with strata FL-PR Florisil solid phase extraction (Anpu Science Instrument Company, Shanghai). Elution was performed with $10 \mathrm{~mL}$ methylene chloride and the sample was concentrated to $0.5 \mathrm{~mL}$ at low temperature before injection under nitrogen stream.

The urea was measured after derivatisation with xanthydrol $0.02 \mathrm{~mol} / \mathrm{L}$ (Sigma-Aldrich, Steinheim, Switzerland) dissolved in 1-propanol using an Aglilent 1200 HPLC (Agilent Technologies, Waldbronn, Germany) equipped with a fluorometric detector set at 213 and $308 \mathrm{~nm}$ (excitation and emission wavelength respectively). Separation was performed on an Eclipse XDB-C18 column $(4.6 \times 150 \mathrm{~mm}, 5 \mathrm{um}$; Agilent Technologies) with the precolumn set at a temperature of $35^{\circ} \mathrm{C}$ (Jiangtao Xing et al., 2011).

The determination of citrulline was based on the Edman reaction as described by Yang et al. (2002). The sample was measured after derivatisation with triethylamine $(1 \mathrm{~mol} / \mathrm{L})$ and phenyl isothiocyanate (PITC) $(100 \mathrm{mmol} / \mathrm{L})$. The chromatographic conditions employed were as follows: an
Agilent 1200 HPLC system with ultraviolet detector and a $\mathrm{C}_{18}$ column $(250 \times 4.6 \mathrm{~mm}$, particle size $5 \mathrm{um})$ was obtained from Agilent. The column temperature was $40^{\circ} \mathrm{C}$ with a $1.0 \mathrm{~mL} / \mathrm{min}$ flow velocity. A $5.0 \mu \mathrm{L}$ aliquot of sample was used and the measurement wavelength was $254 \mathrm{~nm}$.

\section{Statistical analysis}

Data processing was performed using the parameters of the dynamic model that were obtained from non-liner matching of the dynamic equation with Origin 9.0 Graphing and Analysis Software (OriginLab, Northampton, MA).

\section{RESULTS AND DISCUSSION}

\section{Effects of the storage temperature on the concentration of urea}

Urea and ethanol can continue to react in wine during storage and thus the concentration of urea can be reduced as a function of time. The first experiment placed wines at $15^{\circ} \mathrm{C}$, $20^{\circ} \mathrm{C}, 25^{\circ} \mathrm{C}$ and $30^{\circ} \mathrm{C}$ with $5.1 \mathrm{mg} / \mathrm{L}$ of urea and followed the change in urea concentration for 200 days of storage (Fig. 1).

The urea concentration reduced logarithmically in the wine during storage. The reduction in urea concentration was very fast at the initial storage times, but slowed at later time points. The change in urea concentration had similar trends to that of other wines with different initial urea concentrations. Neither the concentration nor natural logarithm of concentration changed linearly with time. Thus, the degradation of urea in wine during storage does not fit a first-order reaction dynamic. This is in sharp contrast to the findings in the work of Larcher et al. (2013). The reason could be the lower storage temperature and higher initial urea concentrations.

In Fig. 1, the urea concentration approaches equilibrium versus time in wines during storage. Here, the test refers to the standard integrated rate law (Equation 3) for a first-order reaction approaching equilibrium, as studied by Hasnip et al. (2004):

$[\mathrm{U}]_{t}=[\mathrm{U}]_{0}\left[\frac{k_{2}+k_{1} e^{-\left(k_{1}+k_{2}\right) t}}{k_{2}+k_{1}}\right]$

where $k_{1}$ is the rate constant for the degradation of urea and $\mathrm{k}_{2}$ is the rate constant for the reformation of urea.

Using Origin 9.0 software to plot the urea concentration in wine during storage and equation 1 with fixed [U], we can calculate many parameters (Table 1 ). Where $\mathrm{k}_{1}$ is the rate constant for the degradation of urea, $\mathrm{k}_{2}$ is the rate constant for the reformation of urea, $[\mathrm{u}]_{t}$ is the concentration of urea at time $\mathrm{t}$, and $[\mathrm{u}]_{0}$ is the concentration of urea at time 0 .

The matching equations at different storage temperatures had different initial concentrations of urea and reached a very significant level $(0.01<\mathrm{P})$. Indeed, Equation 3 could present the change in urea concentration in wines during storage. The reaction rate increased with the temperature in samples with a urea concentration of $5.1 \mathrm{mg} / \mathrm{L}$. In this test, if the temperature increased by $10^{\circ} \mathrm{C}$, the reaction rate increased 1.8-fold. 


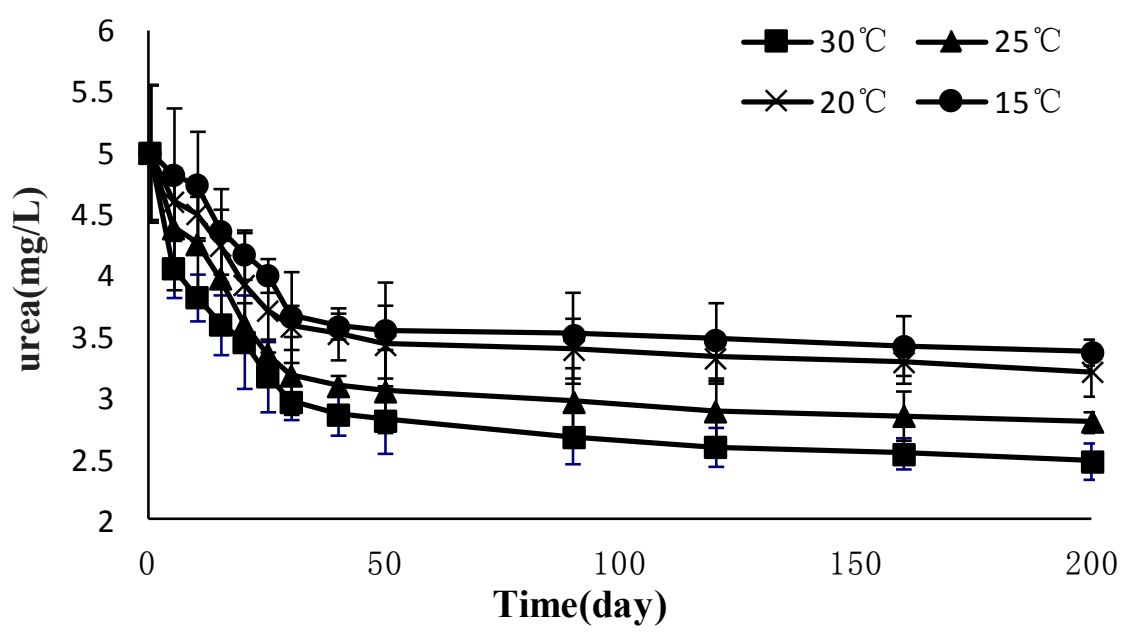

FIGURE 1

Evolution of urea contents in wine during storage at different temperatures. The parameters of the initial wines were the same. At each temperature, three independent wines were analysed. Values are the mean of three repetitions. Bars indicate standard deviation.

TABLE 1

The matching dynamic equations and parameters of urea reactions in different wines during storage.

\begin{tabular}{|c|c|c|c|c|c|}
\hline $\begin{array}{l}\text { The initial } \\
\text { concentrations } \\
\text { of urea }(\mathrm{mg} / \mathrm{L})\end{array}$ & $\begin{array}{l}\text { Temp. } \\
\left({ }^{\circ} \mathrm{C}\right)\end{array}$ & Equation & $\begin{array}{l}\text { Matching } \\
\text { correlation } \\
\text { index }\left(\mathrm{R}^{2}\right)\end{array}$ & $\mathrm{K}_{1}$ & $\mathrm{~K}_{2}$ \\
\hline \multirow{4}{*}{5.1} & 15 & {$[u]_{t}=[u]_{0} \times\left[\frac{0.02666+0.01268 \exp ^{-(0.01268+0.02666) t}}{0.01268+0.02666}\right]$} & 0.9535 & 0.01268 & 0.02666 \\
\hline & 20 & {$[u]_{t}=[u]_{0} \times\left[\frac{0.03114+0.01637 \exp ^{-(0.01637+0.03114) t}}{0.01637+0.03114}\right]$} & 0.98009 & 0.01637 & 0.03114 \\
\hline & 25 & {$[u]_{t}=[u]_{0} \times\left[\frac{0.03005+0.02252 \exp ^{-(0.02252+0.03005) t}}{0.02252+0.03005}\right]$} & 0.98421 & 0.02252 & 0.03005 \\
\hline & 30 & {$[u]_{t}=[u]_{0} \times\left[\frac{0.03193+0.02932 \exp ^{-(0.02932+0.03193) t}}{0.02932+0.03193}\right]$} & 0.97221 & 0.02932 & 0.03193 \\
\hline \multirow{2}{*}{10.1} & 15 & {$[u]_{t}=[u]_{0} \times\left[\frac{0.01797+0.01487 \exp ^{-(0.01487+0.01797) t}}{0.01487+0.01797}\right]$} & 0.9681 & 0.01487 & 0.01797 \\
\hline & 20 & {$[u]_{t}=[u]_{0} \times\left[\frac{0.02431+0.02051 \exp ^{-(0.02051+0.02431) t}}{0.02051+0.02431}\right]$} & 0.97428 & 0.02051 & 0.02431 \\
\hline \multirow{4}{*}{15.1} & 25 & {$[u]_{t}=[u]_{0} \times\left[\frac{0.017+0.02309 \exp ^{-(0.02309+0.017) t}}{0.02309+0.017}\right]$} & 0.95257 & 0.02309 & 0.017 \\
\hline & 15 & {$[u]_{t}=[u]_{0} \times\left[\frac{0.04462+0.02877 \exp ^{-(0.02877+0.04462) t}}{0.02877+0.04462}\right]$} & 0.99251 & 0.02877 & 0.04462 \\
\hline & 20 & {$[u]_{t}=[u]_{0} \times\left[\frac{0.03465+0.03259 \exp ^{-(0.03259+0.03465) t}}{0.03259+0.03465}\right]$} & 0.96896 & 0.03259 & 0.03465 \\
\hline & 25 & {$[u]_{t}=[u]_{0} \times\left[\frac{0.02977+0.03799 \exp ^{-(0.03799+0.02977) t}}{0.03799+0.02977}\right]$} & 0.97141 & 0.03799 & 0.02977 \\
\hline \multirow{3}{*}{20.1} & 15 & {$[u]_{t}=[u]_{0} \times\left[\frac{0.0417+0.0331 \mathrm{exp}^{-(0.0331+0.0417) t}}{0.0331+0.0417}\right]$} & 0.95664 & 0.0331 & 0.0417 \\
\hline & 20 & {$[u]_{t}=[u]_{0} \times\left[\frac{0.0558+0.04384 \exp ^{-(0.04384+0.0558) t}}{0.04384+0.0558}\right]$} & 0.94264 & 0.04384 & 0.0558 \\
\hline & 25 & {$[u]_{t}=[u]_{0} \times\left[\frac{0.04664+0.04628 \exp ^{-(0.04628+0.04664) t}}{0.04628+0.04664}\right]$} & 0.94646 & 0.04628 & 0.04664 \\
\hline
\end{tabular}


The Arrhenius equation is $\mathrm{K}=\mathrm{A} \exp \left(-\frac{E a}{R T}\right)$, where $\mathrm{k}$ means rate constant, $\mathrm{T}$ means absolute temperature, and $\mathrm{R}$ means gas constant $(8.314 \mathrm{~J} / \mathrm{mol})$. The activation energy for the decay of urea was calculated from the Arrhenius plot to be $41.106 \mathrm{~kJ} / \mathrm{mol}$. The rate of urea degradation is different if the initial urea concentration is different, even at the same temperature. A higher initial urea concentration implies a faster reaction rate. The rate constant in wine with urea concentrations of $15.1 \mathrm{mg} / \mathrm{L}$ is twice that of wine with a urea concentration of $5.1 \mathrm{mg} / \mathrm{L}$. Indeed, not only the temperature, but also the reactant concentrations, affects the degradation of urea.

Effects of the storage temperature on the EC concentration of wine

To investigate the effect of temperature on EC concentration during storage, the fresh Cabernet Sauvignon red wines were kept at different temperatures $\left(15^{\circ} \mathrm{C}, 20^{\circ} \mathrm{C}, 25^{\circ} \mathrm{C}\right.$ and $\left.30^{\circ} \mathrm{C}\right)$. As can be seen from Figs 1 and 2, the reaction between ethanol and urea continued with time. Because urea is the major precursor for the formation of EC, the change in urea concentration could lead to changes in the EC concentration. The concentration of EC shows a logarithmic increase when the urea concentration is decreased in wines at different temperatures (Fig. 2).

The change in EC concentration is the opposite of urea during storage. The longer the time, the more EC is produced. Here, the concentration of EC increased rapidly at first and then increased slowly. Higher EC concentrations were found at higher temperatures. These were 1.5 to two times higher at $30^{\circ} \mathrm{C}$ than those at $15^{\circ} \mathrm{C}$ after 30 days of storage. It shows that the concentration of EC does not exceed $15 \mu \mathrm{g} / \mathrm{L}$, so storage at low temperatures could limit the increase in EC concentration.

\section{Effects of the initial urea concentration on the EC} concentration in wine

Consistent with previous studies, the concentrations of EC and urea have a directly proportional relationship (Monteiro et al., 1989; Stevens \& Ough, 1993; Kodama et al., 1994). Our test followed the change in EC concentration in wines that have different initial concentrations of urea (Fig. 3).

Figure 3 illustrates that the formation of EC was rapid at first, but then reached equilibrium. With lower initial urea concentrations, equilibrium is reached sooner and less EC is yielded. With higher initial urea concentrations, high EC levels were found after storage. According to the data in Fig. 2, the change in EC concentration at different times (d $[\mathrm{EC}] / \mathrm{dt})$, combined with $\mathrm{d}$ [urea]/dt from Fig. 2, yields a straight line. Indeed, the formation of EC has a direct and proportional relationship between the changes in urea concentration. The slope of the straight line is the rate constant, $\mathrm{Ku}$, for the formation of EC from urea. Similarly, the rate constant, $\mathrm{Kc}$, for the formation of EC from citrulline could be calculated (Table 2).

At $30^{\circ} \mathrm{C}$, the $\mathrm{Ku}$ and $\mathrm{Kc}$ were 0.0024 and 0.0004 , respectively. These differ slightly from the figures obtained in Hasnip et al.'s studies (2004), which showed $\mathrm{Ku}$ and $\mathrm{Kc}$ to be 0.0012 and 0.00018 respectively at $28^{\circ} \mathrm{C}$. The storage

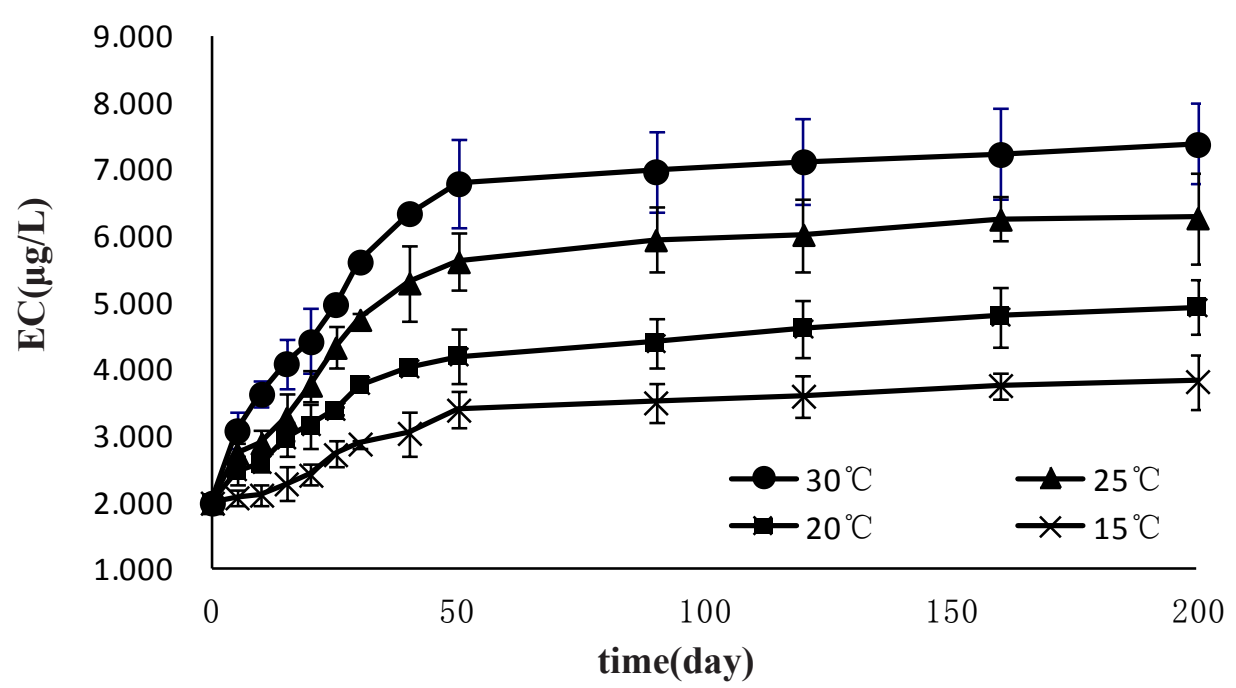

FIGURE 2

Evolution of EC contents in wine during storage at different temperatures. The parameters of the initial wines were the same. At each temperature, three independent wines were analysed. Results are expressed as mean values \pm standard errors.

TABLE 2

The different rate constants, $\mathrm{Ku}$ (the formation of $\mathrm{EC}$ from urea) and $\mathrm{Kc}$ (the formation of $\mathrm{EC}$ from citrulline)

\begin{tabular}{lcccccccc}
\hline Temperature & \multicolumn{2}{c}{$30^{\circ} \mathrm{C}$} & \multicolumn{2}{c}{$25^{\circ} \mathrm{C}$} & \multicolumn{2}{c}{$20^{\circ} \mathrm{C}$} & \multicolumn{2}{c}{$15^{\circ} \mathrm{C}$} \\
& $\mathrm{K}$ & $\mathrm{R}^{2}$ & $\mathrm{~K}$ & $\mathrm{R}^{2}$ & $\mathrm{~K}$ & $\mathrm{R}^{2}$ & $\mathrm{~K}$ & $\mathrm{R}^{2}$ \\
\hline $\mathrm{Ku}$ & 0.0024 & 0.9623 & 0.0023 & 0.9524 & 0.0016 & 0.9708 & 0.0012 & 0.963 \\
$\mathrm{Kc}$ & 0.0004 & 0.9653 & 0.0003 & 0.9338 & 0.0003 & 0.9456 & 0.0002 & 0.9656 \\
\hline
\end{tabular}




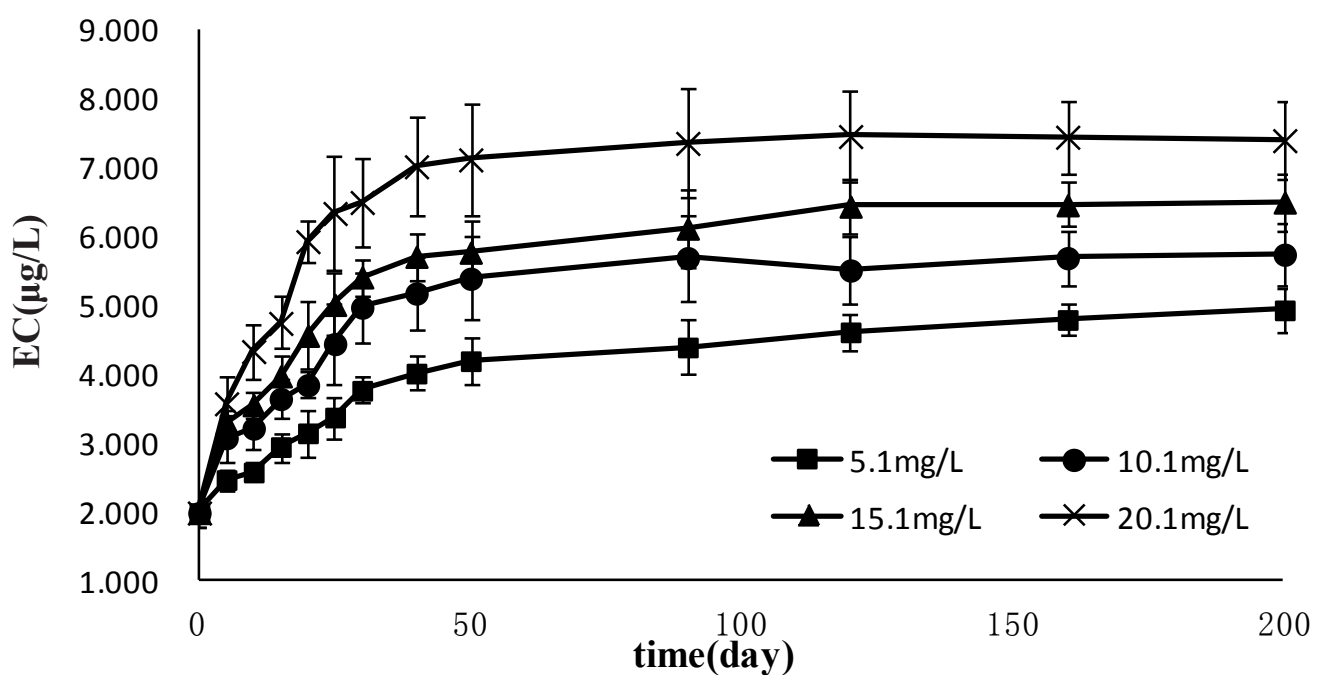

FIGURE 3

Evolution of EC contents in wine during storage at $20^{\circ} \mathrm{C}$. The initial concentration of urea in the wine was $5.1 \mathrm{mg} / \mathrm{L}, 10.1$ $\mathrm{mg} / \mathrm{L}, 15.1 \mathrm{mg} / \mathrm{L}$ and $20.1 \mathrm{mg} / \mathrm{L}$, respectively. Experiments were carried out in triplicate. Data shown correspond to average and standard deviations.

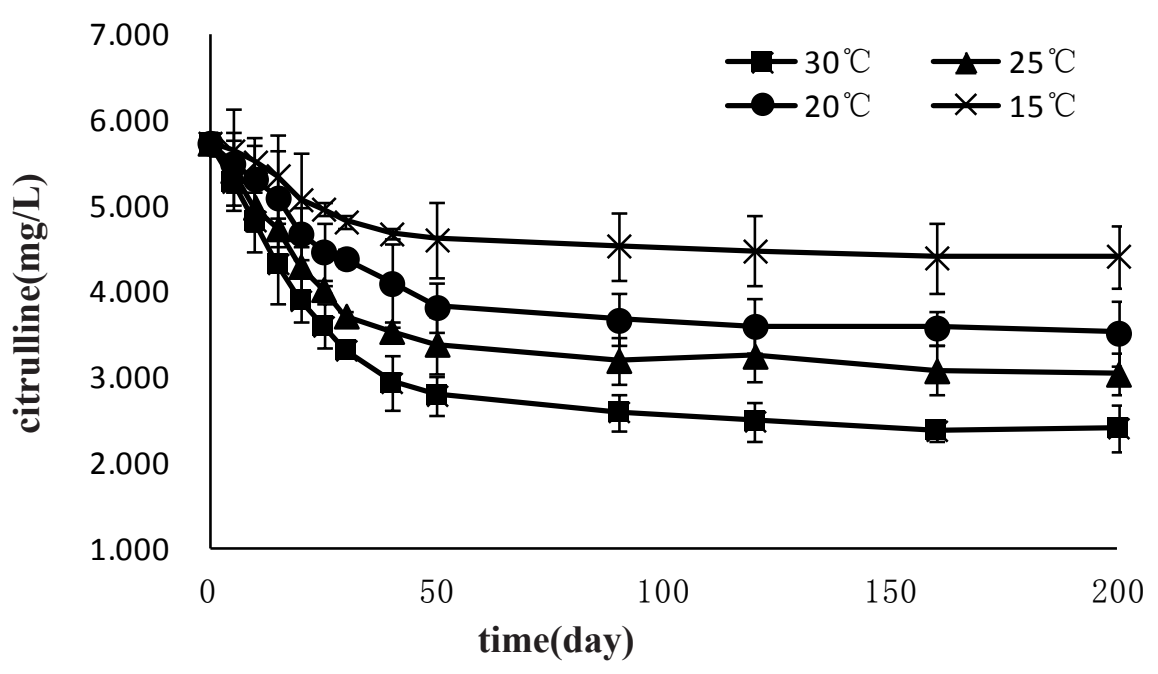

FIGURE 4

Evolution of citrulline contents in wine during storage at different temperatures. The parameters of the initial wines were the same. At each temperature, three independent wines were analysed. Values are the mean of three repetitions. Bars indicate standard deviation.

TABLE 3

The matching dynamic equations and parameters of the citrulline reaction at different temperatures during storage

\begin{tabular}{|c|c|c|c|c|}
\hline Temperature $\left({ }^{\circ} \mathrm{C}\right)$ & Equation & $\begin{array}{l}\text { Matching correlation } \\
\text { index }\left(\mathrm{R}^{2}\right) \\
\end{array}$ & K3 & K4 \\
\hline 15 & {$[c]_{t}=[c]_{0} \times\left[\frac{0.02504+0.00757 \exp ^{-(0.00757+0.02504) t}}{0.00757+0.02504}\right]$} & 0.9689 & 0.00757 & 0.02504 \\
\hline 20 & {$[c]_{t}=[c]_{0} \times\left[\frac{0.02395+0.0145 \exp ^{-(0.0145+0.02395) t}}{0.0145+0.02395}\right]$} & 0.9906 & 0.0145 & 0.02395 \\
\hline 25 & {$[c]_{t}=[c]_{0} \times\left[\frac{0.02113+0.01827 \exp ^{-(0.01827+0.02113) t}}{0.01827+0.02113}\right]$} & 0.9849 & 0.01827 & 0.02113 \\
\hline 30 & {$[c]_{t}=[c]_{0} \times\left[\frac{0.01898+0.02728 \exp ^{-(0.02728+0.01898) t}}{0.02728+0.01898}\right]$} & 0.9731 & 0.02728 & 0.01898 \\
\hline
\end{tabular}




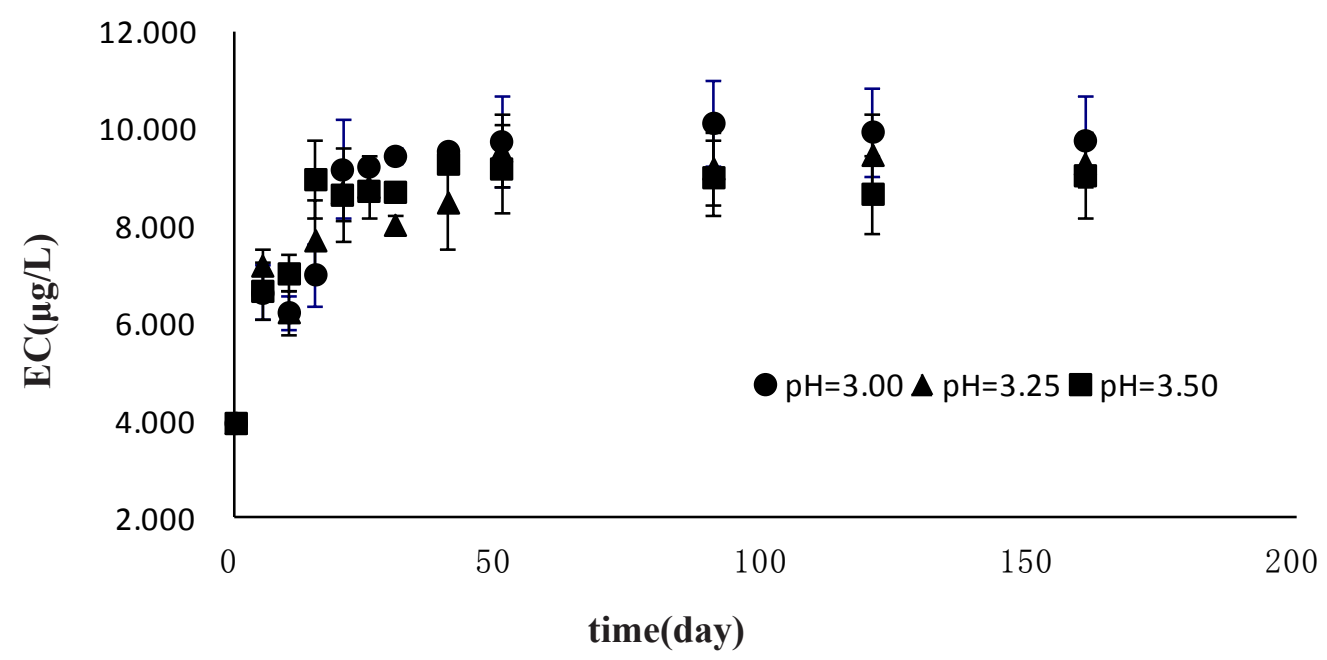

FIGURE 5

Evolution of EC contents in wine during storage at $25^{\circ} \mathrm{C}$ with initial concentration of urea being $5.1 \mathrm{mg} / \mathrm{L}$. The $\mathrm{pH}$ of the wines was 3.00, 3.25 and 3.50 respectively. At each pH, three independent wines were analysed. Data shown correspond to average and standard deviations.

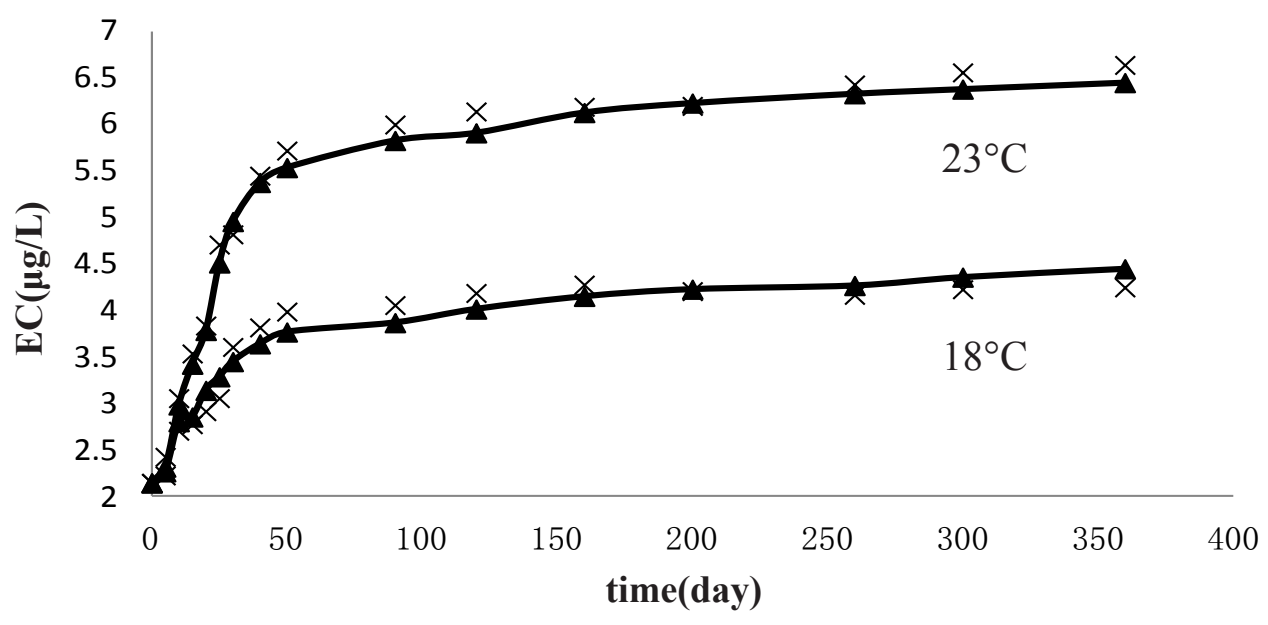

FIGURE 6

Formation of EC over time observed in Merlot wine (-x-) and the corresponding formation predicted by equation 4 (- $\mathbf{\Lambda}_{-}^{-)}$at various temperatures. Values given are the mean of three determinations.

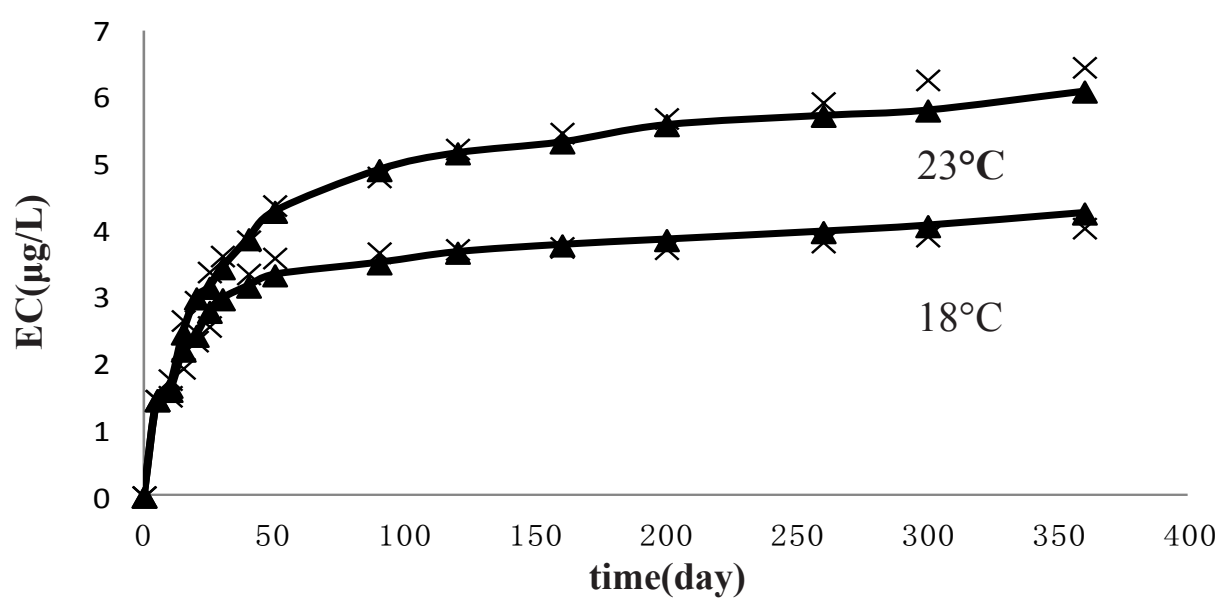

FIGURE 7

Formation of EC over time observed in Chardonnay wine (-X-) and the corresponding formation predicted by equation 4 (- $\mathbf{\Delta}-)$ at various temperatures. Values given are the mean of three determinations. 
temperature increased by $10^{\circ} \mathrm{C}$ and the formation of $\mathrm{EC}$ from urea could thus increase by 1.5 to two times. Activation energy for the formation of EC from urea was calculated from the Arrhenius plot to be $34.037 \mathrm{~kJ} / \mathrm{mol}$. The activation energy for the formation of EC from citrulline was similarly calculated as $66.019 \mathrm{~kJ} / \mathrm{mol}$.

\section{Effects of storage temperature on the concentration of citrulline}

Citrulline is also a major factor that affects the formation of EC in wines. Here, we studied changes in citrulline concentration at different temperatures (Fig. 4). The concentration of citrulline in wine during storage showed a downward trend (Fig. 4). It initially decreased rapidly during storage, and then gradually slowed. This trend is similar to that seen for urea concentration during storage. Using Equation 3 to plot the citrulline concentrations in wines during storage against time, we find the data shown in Table 3.

where $\mathrm{k}_{3}$ is the rate constant for the degradation of citrulline, $\mathrm{k}_{4}$ is the rate constant for the reformation of citrulline, $[\mathrm{c}]_{\mathrm{t}}$ is the concentration of citrulline at time $\mathrm{t}$ and $[\mathrm{c}]_{0}$ is the concentration of citrulline at time 0 . Here we used $5.73 \mathrm{mg} / \mathrm{L}$.

According to $\mathrm{k}_{3}$, temperature has an effect on the decay rate of citrulline. If the temperature increases by $10^{\circ} \mathrm{C}$, the decay rate of citrulline would increase 1.5 to 2.5 times. The effect of temperature on the decay rate of citrulline was greater than the effect on the decay rate of urea. The activation energy for the degradation of citrulline was calculated to be $59.27 \mathrm{~kJ} / \mathrm{mol}$ from the Arrhenius equation according to the rate constant of citrulline at different temperatures. This study used the rate constant for the formation of EC from citrulline in Table 2.

\section{Effects of $\mathrm{pH}$ on the formation of $\mathrm{EC}$ in wines during storage}

The reaction of ethanol with urea or citrulline is acid mediated. Thus, we studied the effect of $\mathrm{pH}$ on the formation of EC using pH 3.00, 3.24 and 3.50 (Fig. 5). The scatter diagram shows that the trend in EC concentration is similar to that seen previously, with little difference for the different $\mathrm{pH}$ values. This is consistent with the observations made by Stevens and Ough (1993), who found that the $\mathrm{pH}$ of a wine does not significantly affect the rate of EC formation. However, the lower $\mathrm{pH}$ wine had a slightly faster formation rate for $\mathrm{EC}$ because the mechanism of EC formation is acid catalysed.

\section{DISCUSSION}

The data shows that the formation of EC in wine depends on the change in urea and citrulline concentrations during storage. This assumes that the urea and citrulline - in reaction with ethanol - are the two major ways to form EC and that the two reactions are independent of each other. The test suggests that the concentration of ethanol remains effectively constant throughout the whole storage time, so the concentration of $\mathrm{EC}$ at time $\mathrm{t}$ could be expressed as

$$
\begin{aligned}
& {[\mathrm{EC}]_{t}=[\mathrm{EC}]_{0}+\mathrm{k}_{u}[\mathrm{EtOH}] \int_{0}^{t}[u] d t+\mathrm{k}_{c}[\mathrm{EtOH}] \int_{0}^{t}[c] d t} \\
& {[\mathrm{U}]_{t}=[\mathrm{U}]_{0}\left[\frac{k_{2}+k_{1} e^{-\left(k_{1}+k_{2}\right) t}}{k_{2}+k_{1}}\right] \text {, }} \\
& \int_{0}^{t}[u] d t=\left.\frac{[u]_{0}}{k_{1}+k_{2}}\left[k_{2} t+\frac{k_{1}\left(1-e^{-\left(k_{1}+k_{2}\right) t}\right)}{k_{1}+k_{2}}\right]\right|_{0} ^{t} \\
& {[c]_{t}=[c]_{0}\left[\frac{k_{4}+k_{3} e^{-\left(k_{3}+k_{4}\right) t}}{k_{3}+k_{4}}\right] \text {, }} \\
& \int_{0}^{t}[c] d t=\left.\frac{[c]_{0}}{k_{3}+k_{4}}\left[k_{4} t+\frac{k_{3}\left(1-e^{-\left(k_{3}+k_{4}\right) t}\right)}{k_{3}+k_{4}}\right]\right|_{0} ^{t} \\
& {[\mathrm{EC}]_{t}=[\mathrm{EC}]_{0}+k_{u}[\mathrm{EtOH}]\{} \\
& \left.\frac{[u]_{0}}{k_{1}+k_{2}}\left[k_{2} t+\frac{k_{1}\left(1-e^{-\left(k_{1}+k_{2}\right) t}\right)}{k_{1}+k_{2}}\right]\right\}+ \\
& k_{c}[\mathrm{EtOH}]\left\{\frac{[c]_{0}}{k_{3}+k_{4}}\left[k_{4} t+\frac{k_{3}\left(1-e^{-\left(k_{3}+k_{4}\right) t}\right)}{k_{3}+k_{4}}\right]\right\}
\end{aligned}
$$

For example, if the calculations were based on a wine being stored for 100 days at $20^{\circ} \mathrm{C},[\mathrm{EC}]_{t}=[\mathrm{EC}]_{0}$

$+[\mathrm{EtOH}]\left(0.118[\mathrm{u}]_{0}+0.0178[\mathrm{c}]_{0}\right)$.

Equation 4 describes the empirical data well for the formation of EC from urea and citrulline in the wines used in this study. To really validate this model, the other bottled wines (white and red) were placed in temperature-controlled storage at 18 and $23^{\circ} \mathrm{C}$ respectively. A similar one-year experiment was carried out to predict the EC concentration using the model, and the prediction then was confirmed with chromatography. The results showed that there was good agreement between the reported data and the data predicated by the equation (Figs 6 and 7). However, it was not possible to test the equation fully, since the experiments in this study were only one year in duration.

\section{CONCLUSIONS}

This study has shown how the concentrations of the major precursors of EC vary during the storage of wine and how this affects the formation of EC. The concentration of urea and citrulline in wine decreases during storage - rapidly at first, and then more slowly. The rate constants were measured for the formation of EC from the urea and citrulline precursors.

Temperature is another major factor that affects the formation of EC. When temperature increased by $10^{\circ} \mathrm{C}$, the formation of EC from urea and citrulline increased by 1.5 to two and 1.5 to 2.5 times, respectively.

We concluded that equation 4 may be used to accurately predict EC levels for a given time/temperature profile. The results are in good agreement with data obtained from similar studies (Hasnip et al., 2004).

\section{LITERATURE CITED}

Beland, F.A., Wayne, B.R., Mellick, P.W., Kovatch, R.M., Roberts, D.W., Fang, J.L. \& Doerqe, D.R., 2005. Effect of ethanol on the tumorigenicity of urethane (ethyl carbamate) in B6C3F1 mice. Food Chem. Toxicol. 43, 1-19. 
Delledonne, D., Rivetti F. \& Romano, U., 2001. Developments in the production and application of dimethylcarbonate. Appl. Catal. A-Gen. 221(2), 241-251.

De Melo Abreu, S., Alves, A., Oliveira, B. \& Herbert, P., 2005. Determination of ethyl carbamate in alcoholic beverages: An interlaboratory study to compare HPLC-FLD with GC-MS methods. Anal. Bioanal. Chem. 382, 498-503.

Hasnip, S., Caputi, A., Crews, C. \& Brereton, P., 2004. Effect of storage time and temperature on the concentration of ethyl carbamate and its precursors in wine. Food Addit. Contam. 21(12), 1155-1161.

Kodama, S., Suzuki, T. \& Fujinawa, S., 1994. Urea contribution to ethyl carbamate formation in commercial wines during storage. Am. J. Enol. Vitic. $45,17-24$.

Lachenmeier, D.W., Kanteres, F., Kuballa, T, Lopez, M.G. \& Rehm J., 2009. Ethyl carbamate in alcoholic beverages from Mexio (tequila, mescal, stool) and Guatemala (cuxa): Market survey and risk assessment. Int. J. Environ. Res. Public Health. 6(1), 349.

Larcher, R., Moser, S., Menolli, A.U., Tonidandel, L. \& Nicolini, G., 2013. Ethyl carbamate formation in sub-optimal wine storage conditions and influence of the yeast starter. J. Int. Sci. Vigne Vin 47(1), 65-68.

Liang, X.H., Sun, J.L. \& Zeng, J., 2009. The formaton and quality control of ethyl carbamate in wines. Liquor-making Sci. Technol.10, 32-36.

Liu, S.Q., Pritchard, G.G., Hardman, M.J. \& Pilone, G.J., 1994. Citrulline production and ethyl carbamate (urethane) precursor formation from arginine degradation by wine lactic acid bacteria Leuconostoc oenos and Lactobacillus buchneri. Am. J. Enol. Vitic. 45, 235-242.

Miller, Y.E., Dwyer-Nield, L.D., Keith, R.L., Le M., Franklin, W.A. \& Malkinson, A.M., 2003. Induction of a high incidence of lung tumors in C57BL/6mice with multiple ethyl carbamate injection. Cancer Letts.198, $139-144$.
Monteiro, F.F., Trousdale, E.K. \& Bisson, L.F., 1989. Ethyl carbamate formation in wine: Use of radioactively labeled precursors to demonstrate the involvement of urea. Am. J. Enol. Vitic. 40, 1-8.

Ough, C.S.(1976). Ethyl carbamate in fermented beverages and foods . Journal of Agricultural and Food chemistry. 24:323-328.

Ough, C.S., Crowell, E.A. \& Gotlove, B.R., 1988. Carbamyl compound reactions with ethanol. Am. J. Enol. Vitic. 39, 239-242.

Park, S.R., Ha, S.D. \& Yoon, J.H., 2009. Exposure to ethyl carbamate in alcohol-drinking and nondrinking adults and its reduction by simple charcoal filtration. Food Control. 20(10), 946-952.

Stevens, D.F. \& Ough, C.S., 1993. Ethyl carbamate formation: reaction of urea and citrulline with ethanol in wine under low to normal temperature conditions. Am. J. Enol. Vitic. 44, 309-312.

Uthurry, C.A., Varela, F., Colomo, B., Suárez Lepe, J.A., Lombardero, J. \& García del Hierro, J.R., 2004. Ethyl carbamate concentrations of typical Spanish red wines. Food Chem. 88(3), 329-336.

Wang, D., Yang, B., Zhai, X. \& Zhou, L., 2007. Synthesis of diethyl carbonate by catalytic alcoholysis of urea. Fuel Process. Technol. 88(8), 807-812.

Weber, J.V. \& Sharypov, V.I., 2009. Ethyl carbamate in foods and beverages: A review. Environ. Chem. Lett. 7, 233-247.

Wu S.J. \& Wang H.X., 2009. The study evolve of ethyl carbamate in fermented foods. Chem. Biol. Engin. 9, 15-18.

Xing J.T., Zhong Q.D., Xiong, Z.H., Zou, H.J. \& Zhou J.D., 2011.The method of HPLC-fluorescence detector to test the concentration of urea in yellow rice or millet wines. Liquor-making Sci. Technol. 3, 104-106.

Yang, Q., Sun, L.G. \& Bai, X.Z., 2002. The HPLC method for using Phenyl isothiocyanate derived before chromatographic column to test 18 kinds of amino acids. Chromatographic 20(4), 369-370. 